\title{
FACTORS ASSOCIATED WITH THE UPTAKE OF VISUAL INSPECTION ACETIC ACID AMONG WOMEN IN SIDOARJO, EAST JAVA
}

\author{
Tri Ratih Agustina \\ Faculty of Medicine, Universitas Wijaya Kusuma Surabaya
}

\begin{abstract}
Background: Cervical cancer continues to be a major public health problem in the absence of wide spread organized cervical screening programs. Visual inspection of the cervix with acetic acid (VIA) is an effective, inexpensive screening test that can be combined with simple treatment procedures for early cervical lesions, provided by trained health workers. This study aimed to determine factors associated with the uptake of VIA among women in Sidoarjo, East Java.
\end{abstract}

Subjects and Method: This was a cross sectional study conducted at Puskesmas (Community Health Center) Buduran, Sidoarjo, East Java. A sample of 77 women of reproductive age was selected for this study by simple random sampling. The dependent variable was VIA uptake. The independent variables were age, education level, employment, parity, knowledge, attitude, information access, family support, and health worker support. The data were collected by questionnaire and analyzed by chi-square test with OR is a measure of association.

Results: VIA uptake was positively associated with working outside the house $(\mathrm{OR}=4.92 ; 95 \% \mathrm{CI}=1.14$ to $21.28 ; \mathrm{p}=0.044)$, good knowledge $(\mathrm{OR}=6.87 ; 95 \% \mathrm{CI}=$ 1.59 to 29.56; $\mathrm{p}=0.008)$, information access $(\mathrm{OR}=0.04 ; 95 \% \mathrm{CI}=0.01$ to $0.21 ; \mathrm{p}=$ 0.00o), family support $(\mathrm{OR}=1.26 ; 95 \% \mathrm{CI}=1.09$ to $1.47 ; \mathrm{p}=0.011)$, health worker support $(\mathrm{OR}=0.04 ; 95 \% \mathrm{CI}=0.01$ to $0.17 ; \mathrm{p}<0.001)$.

Conclusion: VIA uptake is positively associated with working outside the house, good knowledge, information access, family support, and health personal support.

Keywords: visual inspection acetic acid, working outside the house, knowledge, information access, family support, health personal support.

\section{Correspondence:}

Tri Ratih Agustina. Faculty of Medicine, Universitas Wijaya Kusuma Surabaya, East Java. Email: wildrizky@gmail.com. Mobile: 0811372336. 